\title{
Питання психології
}

Теслик Н. М., кандидат психологічних наук, Сумський держсавний університет ORCID ID 0000-0002-1564-8323;

Коляда Н. В., кандидат психологічних наук, Сумський державний педагогічний університет ORCID ID 0000-0003-3623-6552

\section{АГРЕСИВНІСТЬ У СТРУКТУРІ ОСОБИСТІСНИХ КОМПЕТЕНТНОСТЕЙ ПАТРУЛЬНИХ ПОЛЩЕЙСЬКИХ У ПЕРІОД ПЕРВИННОЇ ПІДГОТОВКИ}

В межах компетентнісного підходу досліджено специфічні особистісні прояви агресивності слухачів на етапі професійного навчання патрульних поліщейських. Проаналізовано корелячійні взаємозв'язки між характерологічними властивостями та проявами агресивності особистості слухача первинної підготовки патрульної поліиії.

Ключові слова: особистісна компетентність, професійна компетентність, характерологічна особливість, агресивність, соиіальна адаптаџія, первинна підготовка патрульних поліцейських.

В рамках компетентносного подхода исследовано спечифические личностные проявления агрессивности слушателей на этапе профессионального обучения патрульных полицейских. Проанализированы корреляционные взаимосвязи мељду характерологическими свойствами и проявлениями агрессивности личности слушателя первичной подготовки патрульной полиции.

Ключевые слова: личностная компетентность, профессиональная компетентность, характерологическая особенность, агрессивность, соииальная адаптаџия, первичная подготовка патрульных полицейских.

Постановка проблеми. Професійна діяльність поліцейських базується на особливій стратегії реалізації службових завдань захисту правопорядку. Специфічність даної професійної діяльності, а також підвищений соціальний контроль за ii здійсненням, постійний цілеспрямований та громадський аналіз отриманих результатів формують систему особливих вимог до особистості поліцейського, а відповідно, і до його підготовки, особливо первинної.

Професійна діяльність патрульного детермінується комплексом суб'єктивних та об'єктивних факторів у взаємовпливах середовища та правової активності індивіда. Сучасна служба поліцейського патрулювання переживає кардинальне реформування, пов'язане із переорієнтацією базових цінностей, засад добору працівників, професійної підготовки, подолання кадрової нестабільності та функціонування поліції у цілому. Відбір претендентів базується не лише на безпосередньо професійних якостях кандидата, але передбачає врахування характерологічних особливостей індивіда, внутрішнього потенціалу та здатності відповідати встановленим вимогам.

Аналіз останніх досліджень i публікацій. Очевидно, що завдання організації процесу набуття особистістю професійних компетенцій покладено на період первинної підготовки. Окремі психологічні аспекти становлення особистості поліцейського на етапі професійної підготовки досліджували Л.М. Балабанова, В.І. Барко, І.В. Воробйова, Л.М. Гайсіна, О.В. Землянська, С.О. Гарькавець, Ю.Б. Ірхін, М.П. Лукашевич， С.С. Пальчевський, .М. Цільмак та інші. Проте питання ролі особистісних якостей у ефективності оволодіння професією поліцейського, набуття професійних компетентностей під час первинної підготовки патрульних лишається актуальним.

Мета статті. Метою нашого дослідження $\epsilon$ проаналізувати прояви агресивності індивіда у структурі особистісних компетентностей у період первинної підготовки патрульних поліцейських.

Виклад основного матеріалу. Досягнення мети вимагає чіткого термінологічного розуміння. Якщо питання агресивності особистості у психологічній літературі відображено відносно однозначно, то до визначення понять «компетенція» та «компетентність» існують відмінні підходи. Найбільш типово дефініцію компетенції пов'язують iз генеративною здатністю здійснювати певну діяльність, мати повноваження та можливості для їхньої реалізації. Психологічна енциклопедія, розглядаючи компетентність 3 позиції рівня кваліфікації фахівця, приділяе увагу трьом аспектам: ступінь оволодіння необхідними 


\section{Питання психології}

навичками, юридична відповідність та професійний досвід [5]. Б.І. Хасан обгрунтовує поняття компетенція 3 точки зору мети діяльності, а компетентність результатів цієї діяльності $[8,107]$.
В.В. Бондаренко,
С.М. Решко,

O.I. Смчук розглядають компетентність як похідну від компетенції та характеризують індивідуальну специфіку кожного окремого суб'єкта як носія компетенції. Це не тільки наявність знань i досвіду, а й уміння їх використовувати для здійснення своїх функцій; це підхід до знання як інструменту розв'язання життєвих проблем, прийняття ефективних рішень у різних сферах життєдіяльності людини. Можна погодитися, що компетентність - це ступінь кваліфікації працівника, який забезпечує можливість успішного виконання актуальних професійних завдань.

Типово до структури професійної компетентності індивіда включають знання і вміння, що визначають результативність професійної діяльності; обсяг навичок виконання професійних завдань; вектор професіоналізації; єдність теоретичної та практичної готовності до професійної діяльності; відповідна аксіологічна наповненість професійної діяльності [2, 8384]. Певною мірою це відображає зовнішні аспекти реалізації службових повноважень. Водночас, не менш важливими, а в деяких випадках i визначальними можуть бути внутрішньоособистісні аспекти професійної самореалізації. Характерологічні якості індивіда позначаються на етичності ділового спілкування [4, 86], здатності до самоконтролю, вмотивованості службової діяльності тощо.

O.M. Цільмак пояснює дану взаємозалежність у межах системного підходу, виокремлюючи у структурі компетентності особистості діяльнісну, особистісну i соціальну складові. Формування професійної компетентності невіддільне від динамічних перетворень у структурі особистості, взаємопов'язане зі змінами індивіда у Я-позиції та соціальному просторі [11, 129]. Підготовчий період до виконання обов'язків патрульних потребує динамічних змін самосвідомості, настанов та уявлень системи Я-концепції за обмежений час. Йдеться про трансформацію особистісних компетентностей слухачів, які забезпечать подальшу професіоналізацію особистості у період адаптації до служби.

Виконання службових повноважень патрульних поліцейських супроводжують стресогенні, екстремальні умови: специфічні вимоги до часу роботи та реакції, домінування емоцій негативного знаку, підвищена особиста відповідальність, надмірна соціалізованість професії тощо [3, 11]. Останнім часом у суспільстві формується стереотипне уявлення про патрульну поліцію як візуальний образ реформування поліцейської системи загалом, що пояснює підвищену увагу до отриманих результатів. Дефіцит часу для прийняття рішення, якого вимагає реалізація патрульної служби, доповнюється специфічним графіком роботи, тривалим напруженням, роботою у нічний час, високою залежністю діяльності від згуртованості мікрогрупи тощо. Відповідно, характерна для таких умов роботи втома може посилювати прояви характерологічних особливостей індивіда.

Зв'язок між ефективністю виконання діяльності, в якій необхідно виявляти значний рівень психомоторних якостей, i особистісними рисами суб'єкта складний та неоднозначний. 3 одного боку, ефективність реалізації професійних завдань визначає наявність певних психомоторних якостей, $з$ іншого такий прогноз не можна назвати точним $[9,514]$, оскільки корелюється особистісними властивостями індивіда. Сформувати базові особистісні компетентності патрульного - це першочергове завдання первинної підготовки поліщейських.

Навчання патрульної поліції відбувається відповідно до Положення про організацію курсів первинної професійної підготовки (спеціалізації) працівників підрозділів патрульної служби, яке визначає порядок й умови навчання. Навчальний процес на курсах спеціалізації - це система організаційних i навчальних заходів, що спрямовані на отримання правоохоронцями професійних компетентностей $[2,83]$.

Законом України «Про Національну поліцію» від 2 липня 2015 року № 580-VIII визначено партнерський характер взаємодії поліщейських із громадянами (ст. 9), що формує потребу готовності поліцейського до специфічного стилю у взаємодії 3 громадянами. Розглядаючи критерієм комунікативної компетентності здатність 


\section{Питання психології}

особистості підтримувати партнерську позицію у спілкуванні, вміння оріснтуватися в ситуаціях спілкування, слід визнати, що професійні і особистісні компетентності патрульних взаємозалежні. Погоджуємося із Л.В. Сікорською, що належний розвиток комунікативної та соціальної компетентностей поліцейського, забезпечує його міжособистісну ефективність $[8,112]$.

Період професійного навчання майбутніх патрульних $є$ часом надзвичайно інтенсивної професіоналізації особистості, що вимагає відповідних комунікативних, соціальних, загальнокультурних компетентностей. Оскільки час підготовки слухачів відносно короткий (у 2017 році розширений 4 місяців на противагу 2,5 місяцям у 2016 році), про глибинні зміни особистості не йдеться. Однак умотивованість особистості слухача, ефективний вплив практично орієнтованої підготовки дозволяє сформувати певні установки особистості, стимулювати рефлексивний підхід. Таким чином, процес включення особистості у виконання службових повноважень патрульного поліцейського вимагає високого рівня адаптивних можливостей, у тому числі і в аспекті соціальної адаптації.

Методи дослідження. У процесі дослідження застосовані психодіагностичні методики: Фрайбурзький особистісний опитувальник у модифікації FPI-B та опитувальник рівня агресивності Басса Дарки; для аналізу отриманих емпіричних даних - коефіцієнт кореляції Спірмена; проведено спостереження. Вибірку склали 258 осіб (у тому числі 184 чоловіки та 74 жінки), які проходили первинну підготовку патрульних поліцейських у місті Суми. Вік досліджуваних становить від 21 до 33 років, що відповідає визначеним нормативною базою обмеженням відбору патрульних.

$$
\text { Результати спостереження за }
$$

досліджуваною групою дозволяють охарактеризувати осіб, залучених до первинної підготовки патрульних, як переважно умотивованих, готових до активних групових та індивідуальних форм роботи. Експектації слухачів на початковому етапі підготовки відзначаються відсутністю достатньої конкретизованості. Зокрема, серед причин, які пов'язані із вибором майбутньої професійної діяльності, у рівній мірі називаються як бажання реформувати систему, боротьба за справедливість, так і грошове забезпечення, пошук власного призначення тощо. Уявлення про рівень стресового навантаження виконання службових повноважень поліщейськими також у всіх слухачів різний. У значній мірі групова думка орієнтована на висловлювання колег, які мають практичний досвід роботи у системі МВС.

Агресивність як риса характеру патрульного поліцейського, 3 одного боку, визначає цілеспрямованість та наполегливість у досягненні визначеної повноваженнями мети. У суб'єкт-суб'єктній формі соціальної взаємодії службові обов'язки патрульних вимагають особистісної готовності відстоювання законних інтересів громадян та держави на позиціях активної конкуренції. Водночас йдеться лише про контрольовані особистістю прояви, що дозволяють активізувати та організувати діяльність патрульного.

Натомість надмірний рівень агресивності у стресогенних умовах роботи поліщейських патрулів $\epsilon$ провокативним деструктивним фактором. Агресивні дії можуть слугувати засобом досягнення конкретної мети, у тому числі службових повноважень патрульних поліцейських, способом психологічної розрядки, заміщення задоволення блокованої потреби, а також задоволення потреби у самореалізації [7]. Останній варіант слід визнати першочергово несумісним 3 загальною метою існування патрульної поліщії в Україні [6].

Опитувальник FPI-B призначений для діагностики станів i властивостей особистості, які мають першочергове значення для соціальної адаптації. Серед досліджуваних факторів виокремлюють базові (шкали I-IX) та похідні, інтегруючі (шкали X-XII) [1, 175-186]. У досліджуваній групі переважають низькі результати за показниками «депресивність», «невротичність», «емоційна лабільність» та високі - за шкалою «урівноваженість» (див. рис. 1). У групі переважають середні показники спонтанної (123 опитаних, тобто 47,7\%) та реактивної агресивності (153 чол., тобто 59,3\% досліджуваних). Низькі рівні відповідно демонструють 98 осіб (38\%) за критерієм спонтанної агресивності та 48 осіб $(18,6 \%)$ за критерієм реактивної агресивності, високі 37 чол. (14,3\%) та 57 осіб. (22,1\%) відповідно. 


\section{Питання психології}

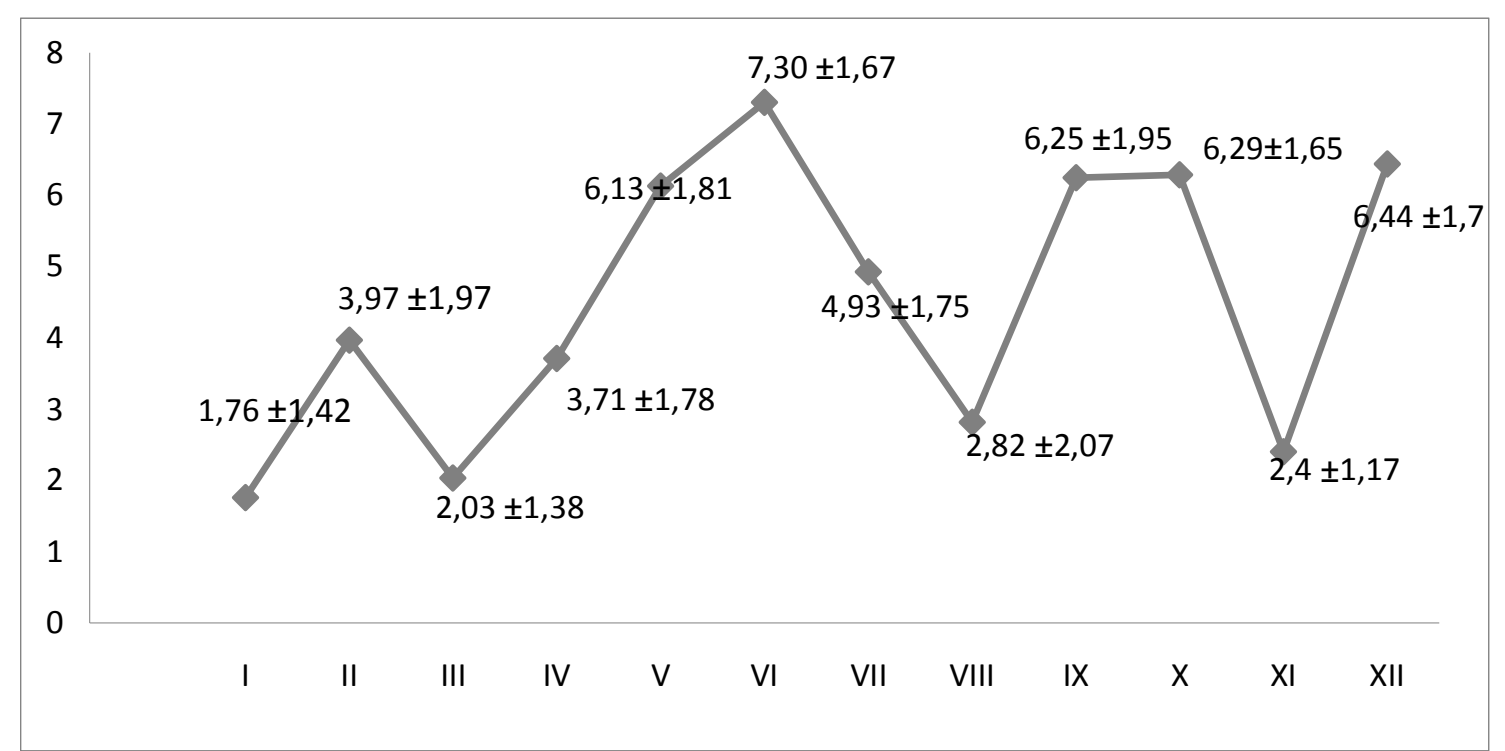

Рис. 1. Профіль групи досліджуваних за особистісними проявами (шкали FPI-B)

Досліджені за допомогою опитувальника Басса - Дарки індекси агресивності та ворожості особистості (див. рис. 2) фіксують показники нижче середньої норми [10, 25-27]: середньозважені показники групи $14,6 \pm 4,09$ при нормі агресивності $21 \pm 4$ та індексу ворожості $3,74 \pm 2,58$ при нормі 6,5-7 \pm 3 . Найменшою мірою для досліджуваної групи властиві опозиційні форми поведінки, негативізм, готовність до вияву подразнення при незначних збудниках, підозрість. Найвищі середньозважені групові показники за критерієм «вербальна агресія», яку можна вважати базовим типом проявом агресивності більшості досліджуваних.

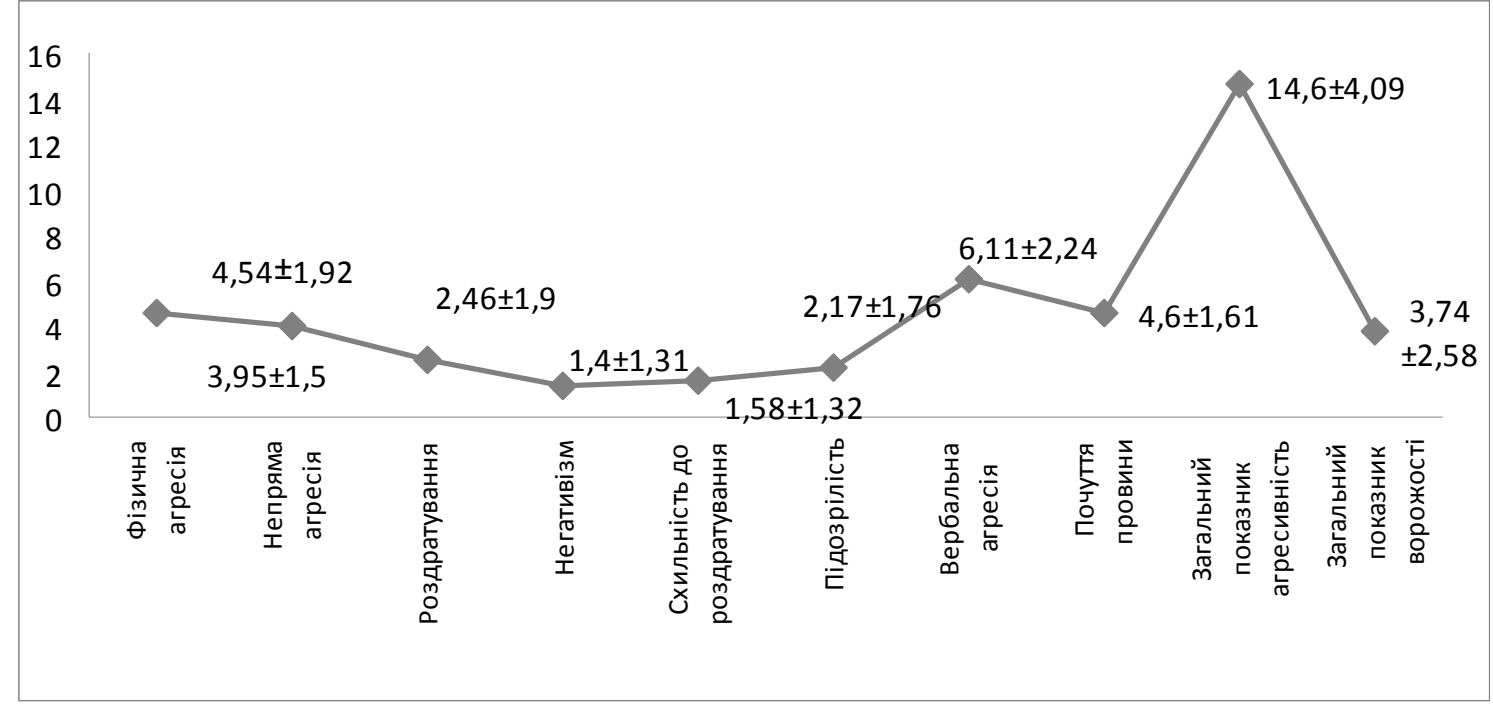

Рис. 2. Профіль групи досліджуваних за проявами агресії

Ці висновки підтверджуються даними спостереження. Слухачі переважно не схильні до агресивних проявів поведінки без достатніх провокативних заохочень, однак в рольових іграх окремі досліджувані здатні втрачати самоконтроль, що свідчить про необхідність стимуляції розвитку стресостійкості особистості. Одними із стимулюючих факторів таких даних слід вважати соціальну ситуацію тренувань та постійної зовнішньої оцінки, яку можна вважати підготовчою до майбутньої професійної самореалізації.
Кореляційний аналіз отриманих даних (табл. 1.) виявляє високу взаємозалежність агресивності та інших особистісних властивостей i станів досліджених. Виключенням $\epsilon$ практично відсутні кореляційні зв'язки між проявами агресивності та товариськості і урівноваженості. Зафіксовано негативні кореляційні зв'язки між урівноваженістю особистості та її схильністю до роздратування (на рівні достовірності $\mathrm{p} \leq 0,01$ ), а також між товариськістю та підозрілістю індивіда (на рівні достовірності $\mathrm{p} \leq 0,05)$. 


\section{Питання психології}

Таблиця 1

Взаємозв'язки показників особистісних властивостей та проявів агресивності слухачів

\begin{tabular}{|c|c|c|c|c|c|c|c|c|c|c|c|}
\hline 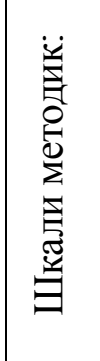 & 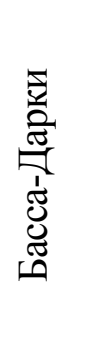 & 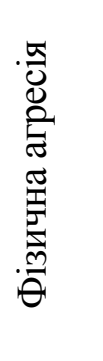 & 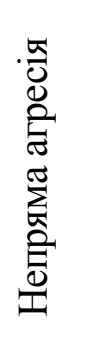 & 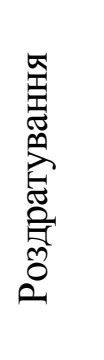 & 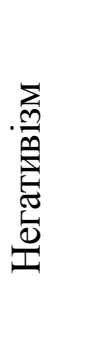 & 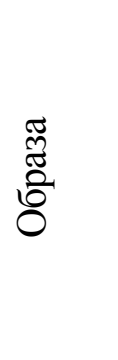 & 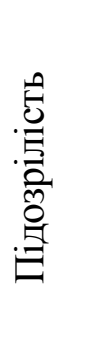 & 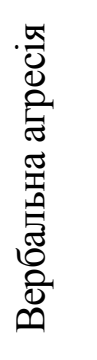 & 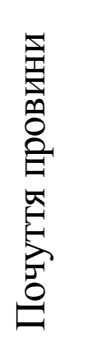 & 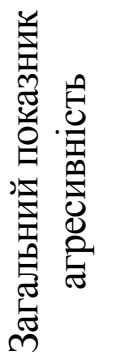 & 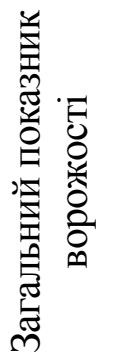 \\
\hline FPI & $\begin{array}{c}(\mathrm{X} \\
\pm \delta) \\
\end{array}$ & $\begin{array}{c}4,54 \pm \\
1,92 \\
\end{array}$ & $\begin{array}{c}3,95 \pm \\
1,5 \\
\end{array}$ & $\begin{array}{c}2,46 \pm \\
1,9 \\
\end{array}$ & $\begin{array}{l}1,4 \pm \\
1,31 \\
\end{array}$ & $\begin{array}{c}1,58 \pm 1 \\
, 32 \\
\end{array}$ & $\begin{array}{c}2,17 \pm \\
1,76 \\
\end{array}$ & $\begin{array}{c}6,11 \pm \\
2,2 \\
\end{array}$ & $\begin{array}{c}4,6 \pm 1 \\
, 61\end{array}$ & $\begin{array}{c}14,6 \pm \\
4,09 \\
\end{array}$ & $\begin{array}{c}3,74 \pm \\
2,58 \\
\end{array}$ \\
\hline I. & $\begin{array}{c}1,76 \pm \\
1,42\end{array}$ & $\begin{array}{c}0.298 \\
*\end{array}$ & $\begin{array}{c}0.406 \\
*\end{array}$ & $\begin{array}{c}0.478 \\
*\end{array}$ & $\begin{array}{c}0.389 \\
*\end{array}$ & $0.415^{*}$ & $\begin{array}{c}0.452 \\
*\end{array}$ & $0.35 *$ & $\begin{array}{c}0,373 \\
*\end{array}$ & $0,381 *$ & $0,465^{*}$ \\
\hline I. & $\begin{array}{c}3,97 \pm \\
1,97\end{array}$ & $0,29 *$ & $\begin{array}{c}0.379 \\
*\end{array}$ & $\begin{array}{c}0.407 \\
*\end{array}$ & $\begin{array}{c}0.369 \\
*\end{array}$ & $0.263^{*}$ & $\begin{array}{c}0.261 \\
*\end{array}$ & $\begin{array}{c}0.341 \\
*\end{array}$ & - & $0,439 *$ & $0.287^{*}$ \\
\hline I. & $\begin{array}{c}2,03 \pm \\
1,38\end{array}$ & - & $0,35 *$ & $\begin{array}{c}0.421 \\
*\end{array}$ & $\begin{array}{c}0.316 \\
*\end{array}$ & $0.426^{*}$ & $\begin{array}{c}0.395 \\
*\end{array}$ & $\begin{array}{c}0,205 \\
*\end{array}$ & $\begin{array}{c}0.355 \\
*\end{array}$ & $0,249^{*}$ & $0.462 *$ \\
\hline t. & $\begin{array}{c}3,71 \pm \\
1,78 \\
\end{array}$ & $\begin{array}{c}0,251 \\
*\end{array}$ & $\begin{array}{c}0.354 \\
*\end{array}$ & $0.54 *$ & $\begin{array}{c}0.429 \\
*\end{array}$ & $\begin{array}{c}0.317 \\
*\end{array}$ & $\begin{array}{c}0.284 \\
*\end{array}$ & $0.48^{*}$ & $\begin{array}{c}0.208 \\
*\end{array}$ & $0,502 *$ & $0.346^{*}$ \\
\hline . & $\begin{array}{c}6,13 \pm \\
1,81\end{array}$ & - & - & - & - & - & $\begin{array}{c}- \\
0.171 \\
* *\end{array}$ & - & - & - & - \\
\hline I. & $\begin{array}{l}, 3 \pm \\
1,67 \\
\end{array}$ & - & - & $\overline{-}-$ & - & - & - & - & - & - & - \\
\hline I. & $\begin{array}{c}4,93 \pm \\
1,75\end{array}$ & $\begin{array}{c}0.513 \\
*\end{array}$ & $\begin{array}{c}0.216 \\
*\end{array}$ & $\begin{array}{c}0.397 \\
*\end{array}$ & $\begin{array}{c}0.391 \\
*\end{array}$ & $\begin{array}{c}0.219 \\
*\end{array}$ & $\begin{array}{c}0.241 \\
*\end{array}$ & $\begin{array}{c}0.366 \\
*\end{array}$ & - & $0,507^{*}$ & $0.259^{*}$ \\
\hline I. & $\begin{array}{c}2,82 \pm \\
2,07 \\
\end{array}$ & - & $\begin{array}{c}0.292 \\
*\end{array}$ & $\begin{array}{c}0.355 \\
*\end{array}$ & $\begin{array}{c}0.15 \\
* *\end{array}$ & $0.285^{*}$ & $\begin{array}{c}0.189 \\
* \\
\end{array}$ & - & $\begin{array}{c}0.239 \\
*\end{array}$ & - & $0.253^{*}$ \\
\hline . & $\begin{array}{c}6,25 \pm \\
1,95 \\
\end{array}$ & $\begin{array}{c}0.284 \\
*\end{array}$ & $\begin{array}{c}0.485 \\
*\end{array}$ & $\begin{array}{c}0.425 \\
*\end{array}$ & $\begin{array}{c}0.464 \\
*\end{array}$ & $0.273^{*}$ & $\begin{array}{c}0.213 \\
* \\
\end{array}$ & $0.27 *$ & $\begin{array}{c}0.214 \\
*\end{array}$ & $0,455^{*}$ & $0.269 *$ \\
\hline . & $\begin{array}{c}6,29 \pm \\
1,65\end{array}$ & $\begin{array}{c}0.227 \\
*\end{array}$ & - & - & $\begin{array}{c}0.195 \\
*\end{array}$ & - & - & $\begin{array}{c}0.245 \\
*\end{array}$ & - & $0,25^{*}$ & - \\
\hline I. & $\begin{array}{l}2,4 \pm \\
1,17\end{array}$ & - & $0,38^{*}$ & $\begin{array}{c}0.461 \\
*\end{array}$ & $\begin{array}{c}0.191 \\
*\end{array}$ & $0.355^{*}$ & $\begin{array}{c}0.184 \\
*\end{array}$ & - & $\begin{array}{c}0.252 \\
*\end{array}$ & $0,193 *$ & $0.305^{*}$ \\
\hline I. & $\begin{array}{c}6,44 \pm \\
1,71\end{array}$ & $\begin{array}{c}0.359 \\
*\end{array}$ & - & - & $\begin{array}{c}0.197 \\
*\end{array}$ & - & - & $\begin{array}{c}0.281 \\
*\end{array}$ & - & $0,31 *$ & - \\
\hline
\end{tabular}

Примітка: * - $\leq \leq 0,01$

Порівняння показників особистісних властивостей та проявів агресивності слухачів первинної підготовки свідчить про найбільш значиму залежність показників невротичності, дратівливості, відкритості у ставленні до оточуючих та проявів агресивності особистості. Невротичний синдром у осіб, які прагнуть оволодіти професією поліцейського, $€$ не лише фактором підвищеної збудливості та втомлюваності, але і стимулом втрати самоконтролю у конфліктних ситуаціях спілкування 3 громадянами. Схильність до роздратування, посиленого афективного реагування унеможливлює ефективну комунікацію патрульних із громадянами та у цілому знижує готовність поліцейського до виконання службових обов'язків. Соціальна відкритість патрульного та готовність до певної самокритичності $\epsilon$ нейтралізуючим чинником стресогенності професії.

Психопатизація інтротенсивного типу, яка обумовлює прагнення до домінування (шкала II методики FPI-B), взаємозалежна із практично усіма дослідженими проявами агресивності особистості, за виключенням аутоагресії, почуттям провини. Також не виявлено залежності між непрямою агресивністю та гендерною ідентифікацією, шкалою екстраверсії - інтроверсії, товариськістю та врівноваженістю. Натомість агресивна поведінка зі зміщеним або відсутнім об'єктом, пов'язана із 


\section{Питання психології}

подразливістю та сором'язливістю індивіда. Передбачувано показники загального рівня агресивності особистості корелюють із показниками невротичності, депресивності, подразливості, емоційної лабільності.

Водночас взаємозв'язки виявлені також між агресивністю та такими особистісними проявами, як відкритість, рівень самокритичності, екстравертованість інтровертованість, рівень гендерної ідентичності особистості. Сором'язливість не входить до переліку домінючих властивостей особистості серед досліджених слухачів первинної підготовки поліції. Найвищий результат за шкалою VIII опитувальника FPI демонструють лише 2 досліджуваних $\quad(0,8 \% \quad$ групи). $\quad \mathrm{y}$ ході спостереження слухачі із високими показниками сором'язливості помітні у підгрупах, при виконанні кейсових завдань виявляють підвищену тривожність, сумніви. Виявлено взаємозалежність даної риси характеру зі схильністю до непрямої агресії, роздратування та спростовує залежність із показниками загальної агресивності, фізичної агресії.

Подолання подібних бар'єрів прогнозовано цілком успішне, не потребує надмірної уваги на етапі відбору кандидатів на підготовку. Однак вимагає забезпечення певної цілеспрямованої особистісної готовності до самовираження у професійній діяльності патрульного.

Описані особливості, на наш погляд, частково мають бути враховані ще на етапі відбору кандидатів на первинну підготовку поліцейських. У той же час існує потреба цілеспрямованого розвитку емоційного інтелекту слухачів як завдання поглиблення навичок самоконтролю у межах аналізу та впливу на прояви власної агресивності.

Висновки та перспективи подальших досліджень. Таким чином, у процесі первинної підготовки патрульних поліщейських недоречно говорити про глибинні особистісні зміни, детерміновані набуттям професійних компетентностей. Однак виявлена взаємозалежність агресивності та особистісних властивостей особистості дозволяе говорити про необхідність віднесення до переліку особистісних компетентностей патрульного, які розвиваються у період первинної підготовки, здатності самоконтролю агресивності.

Саме застосування компетентнісного підходу дозволяє забезпечити підвищення загальнокультурного та професійного рівня особистості, спрямувати систему психологопедагогічних впливів на особистості у процесі підготовки. Оволодіння рівнем власної агресивності $€$ потенційним фактором успішної професійної адаптації патрульних поліцейських.

Можливими варіантами підвищення ефективності запровадження компетентнісного підходу $є$ впровадження тренінгових програм розвитку емоційного інтелекту особистості, розширення курсу дисципліни «Стресостійкість» за рахунок включення проблематики контролю та самоконтролю проявів агресії індивіда, включення відповідних тренінгових занять до плану занять психолога зі слухачами. Під комплексним впливом професійних настанов, зовнішніх умов середовища, практичної діяльності, що грунтується на отриманих компетентностях, відбуваються трансформації особистості, зокрема, формується професійно-правова свідомість поліцейського.

Виходячи із вищевикладеного, ми вважаємо психологічну складову професійного відбору кандидатів на первинну підготовку патрульних поліцейських та психолого-педагогічний комплекс впливів на формування особистісних компетентностей слухачів одними із визначальних чинників подальшої успішної реалізації особистості у сфері підтримання правопорядку.

\section{Список використаних джерел}

1. Батаршев А. В. Темперамент и характер: Психологическая диагностика. - М.: Изд-во ВЛАДОС-ПРЕСС, 2001. - 336 с.

2. Бондаренко В. В. Компоненти професійної компетентності працівників підрозділів патрульної служби Національної поліції України / В.В.Бондаренко, В. В. Решко, О. І. Смчук // Юридична психологія. - 2016. - № 2. - С. 81-90. - Режим доступу: http://nbuv.gov.ua/UJRN/urpp_2016_2_9.

3. Ірхін Ю. Б. Психологічна підготовка працівників оперативних підрозділів. Навч. посіб. - К. : РВЦ КНУВС : Друкарня МВС, 2007. - 94 с. 


\section{Питання психології}

4. Литвин В. В. Професійне спілкування патрульних поліцейських із різними категоріями громадян/ В. В. Литвин // Юридична психологія. - 2016. - № 1. - С. 84-94.

5. Лунячек В. Е. Компетентнісний підхід як методологія професійної підготовки у вищій школі / В. Е. Лунячек // Публічне управління: теорія та практика. - 2013. - Вип. 1. -С. 155-162. - Режим доступу: http://irbis-nbuv.gov.ua/cgi-bin/irbis_nbuv/cgiirbis_64.exe.

6. Про затвердження Положення про патрульну службу МВС. Наказ МВС України від 2 лип. 2015 p. № 796. - Режим доступу: http//zakon0.rada.gov.ua/ laws/show/z0777-15.

7. Психологические тесты для профессионалов /Авт. сост. Н. Ф. Гребень. -Минск: Соврем. шк., 2007. $-496 \mathrm{c}$.

8. Сікорська Л. Б. Зміст комунікативної компетентності працівників ОВС та ії розвиток / Л. Б. Сікорська // Науковий вісник Львівського державного університету внутрішніх справ. Серія психологічна. - 2011. - Вип. 1. - С. 106-119. - Режим доступу: http://nbuv.gov.ua/UJRN/Nvldu_2011_1_11.

9. Сімко Р. Т. Психологічні особливості вияву особистісних рис працівників патрульної поліції / Р. Т. Сімко // Проблеми сучасної психології. Збірник наукових праць К-ПНУ імені Івана Огієнка, Інституту психології імені Г.С.Костюка НАПН України. -Випуск 34. - Кам'янець-Подільський : Аксіома, 2016. - С. 512-521. - Режим доступу: http://irbis-nbuv.gov.ua/cgi-bin/irbis_nbuv/cgiirbis_64.exe.

10.Хван А. А. Стандартизированный опросник измерения агрессивных и враждебных реакций А. Басса и А. Дарки / А. А. Хван , Ю. А. Зайцев, Ю. А. Кузнецова : методические рекомендации. Кемерово: КРИПКиПРО, 2006. - 66 с.

11.Цільмак О. М. Складові структури компетентностей / О. М. Цільмак // Наука і освіта. - К., 2009. - № 1/2. - С. 128-134.

\section{References}

1. Batarshev, A. V. (2001). Temperament y kharakter: Psykholohycheskaia dyahnostyka [Temperament and character: Psychological diagnostics]. M.: Yzd-vo VLADOS-PRESS (in Russian).

2. Bondarenko, V. V., Reshko, V. V., Yemchuk, O. I. (2016). Komponenty profesiinoi kompetentnosti pratsivnykiv pidrozdiliv patrulnoi sluzhby Natsionalnoi politsii Ukrainy [Components of professional competence of employees of units of the patrol service of the National Police of Ukraine]. Yurydychna psykholohiia, 2, 81-90. URL: http://nbuv.gov.ua/UJRN/urpp_2016_2_9. (in Ukrainian).

3. Irkhin, Yu. B. (2007). Psykholohichna pidhotovka pratsivnykiv operatyvnykh pidrozdiliv. [Psychological training of employees of operational units]. K.: RVTs KNUVS : Drukarnia MVS (in Ukrainian).

4. Lytvyn, V. V. (2016). Profesiine spilkuvannia patrulnykh politseiskykh iz riznymy katehoriiamy hromadian [Professional communication of patrol policemen with different categories of citizens]. Yurydychna psykholohiia, 1, 84-94 (in Ukrainian).

5. Luniachek, V. E. (2013). Kompetentnisnyi pidkhid yak metodolohiia profesiinoi pidhotovky u vyshchii shkoli [Competency approach as a methodology for vocational training in higher education]. Publichne upravlinnia: teoriia ta praktyka, 1, 155-162. URL: http://irbis-nbuv.gov.ua/cgibin/irbis_nbuv/cgiirbis_64.exe. (in Ukrainian).

6. Pro zatverdzhennia Polozhennia pro patrulnu sluzhbu MVS [On Approval of the Regulations on the Patrol Service of the Ministry of Internal Affairs]. Nakaz MVS Ukrainy 2 lypnya 2015 r. № 796. URL: http//zakon0.rada.gov.ua/ laws/show/z0777-15. (in Ukrainian).

7. Hreben, N. F. (2007). Psykholohycheskye testy dlia professyonalov [Psychological tests for professionals]. Mynsk: Sovrem. shk. (in Russian).

8. Sikorska, L. B. (2011). Zmist komunikatyvnoi kompetentnosti pratsivnykiv OVS ta yii rozvytok [Content of the communicative competence of ATS employees and its development]. Naukovyi visnyk Lvivskoho derzhavnoho universytetu vnutrishnikh sprav. seriia psykholohichna. 1, 106-119. URL: http://nbuv.gov.ua/UJRN/Nvldu_2011_1_11. (in Ukrainian).

9. Simko, R. T. (2016) Psykholohichni osoblyvosti vyiavu osobystisnykh rys pratsivnykiv patrulnoi politsii [Psychological features of manifestation of personality traits of patrol police officers]. Problemy suchasnoi psykholohii. Zbirnyk naukovykh prats K-PNU imeni Ivana Ohiienka, Instytutu psykholohii imeni H.S.Kostiuka NAPN Ukrainy. Vypusk 34. Kamianets-Podilskyi : Aksioma. URL: http://irbis-nbuv.gov.ua/cgibin/irbis_nbuv/cgiirbis_64.exe. (in Ukrainian).

10.Khvan, A.A., Zaitsev, Yu.A., Kuznetsova, Yu.A. (2006) Standartyzyrovannyi oprosnyk yzmerenyia ahressyvnikh y vrazhdebnikh reaktsyi A. Bassa i A. Darky (The standardized questionnaire for measuring aggressive and hostile reactions of A. Bass and A. Darki). (Metodycheskye rekomendatsyy). Kemerovo: KRYPKyPRO, (in Russian). 


\section{Питання психології}

11.Tsilmak, O. M. (2009). Skladovi struktury kompetentnostei [Components of competency structures]. Nauka i osvita. Naukovo-praktychnyi zhurnal Pivdennoho naukovoho Tsentru APN Ukrainy. Hol. red. Chebykin O. Ya. - K., 1/2, 128-134. (in Ukrainian).

\section{SUMMARY \\ Teslyk $N$., candidate of psychological science \\ Kolyada ., candidate of psychological science \\ THE AGGRESSION IN THE STRUCTURE OF INDIVIDUAL COMPETENCES OF PATROL POLICE IN THE PERIOD OF PRIMARY TRAINING}

Introduction. The article highlights the characterological features of the audience during the primary training of police patrol. The content of the concepts of "competence" and "competence" is defined. Specific traits of listeners training of official duties of patrol police are analysed.

The professional and personal competencies of patrol officers are systemically connected. The article determines the dynamic changes of personal competencies, in particular, the formation of guidelines, awareness of the need for further personal development, which are characteristic for the short term of primary training.

Purpose. The study aims to determine the place of aggressiveness in the structure of personal competencies patrol police officers during primary training.

Methods. Psychodiagnostic methods Freiburg Personality Inventory, FPI, Buss - Durkee Hostility Inventory, observations used to achieve a goal.

Results. The aggressiveness as a personal trait is a professionally significant quality patrol. The need for high self-control of personality and readiness for an active position in the protection of law and order exists in the work of the police. The indexes of aggressiveness and hostility of the group of subjects under the average norm are fixed. Opposition forms of behaviour, negativism, readiness to exhibit irritation with minor pathogens, suspicion are least of a degree for the investigators.

The average indicators of spontaneous and reactive aggression prevail in future patrol officers. Low results for indicators of "neurotic", "depression", "shyness", "emotional lability" and high results on the scale of "balance" prevail in the study group.

The article describes the interrelations between manifestations of personality aggression and such personality manifestations as openness, level of self-criticism, extraversion - introversion, level of gender identity of a person. The aggressiveness of the individual is associated with neuroticism, irritability and selfcriticism.

Originality. Interdependence of personality anxiety with tendency to indirect aggression, irritation was revealed. Propensities to intensified response, increased anxiety are barriers, readiness to overcome which should be formed during the period of primary training of the police.

Conclusion. The inclusion of self-control of manifestations of personality aggression in the list of personal competencies of the students will contribute to the future of professional adaptation of patrol officers.

Keywords: personal competence, professional competence, characterological feature, aggression, social adaptation, primary training of patrol police officers. 